\title{
VISCERAL LEISHMANIASIS CAUSED BY Leishmania (Viannia) braziliensis IN A PATIENT INFECTED WITH HUMAN IMMUNODEFICIENCY VIRUS
}

\author{
Eduardo Sérgio da SILVA(1,2), Raquel Silva PACHECO(3), Célia Maria Ferreira GONTIJO(1), Inácio Roberto CARVALHO(4) \& Reginaldo Peçanha BRAZIL(1)
}

\begin{abstract}
SUMMARY
The current article reports the case of a 19-month-old-girl, from the state of Minas Gerais, Brazil, with visceral leishmaniasis, by Leishmania (Viannia) braziliensis, and Human Immunodeficiency Virus (HIV) co-infection. The child's mother and father, aged 22 and 27 years old, respectively, were both HIV positive. The child was admitted to the General Pediatric Center, in Belo Horizonte, presenting high fever, fatigue, weight loss and enlargement of liver and spleen. Indirect immunofluorescent test revealed a titer of 1:320 for Leishmania. Such result was confirmed by the presence of amastigotes in bone marrow aspirate samples and culture of promastigote forms. Parasites were identified as being Leishmania (Viannia) braziliensis through PCR, using a L. braziliensis complex primer and a generic primer, followed by hibridization. Specific leishmaniasis therapy (Glucantime ${ }^{\circledR}$ antimonial) was intravenously administered.
\end{abstract}

KEYWORDS: Visceral leishmaniasis; Leishmania (Viannia) braziliensis; Human immunodeficiency virus; PCR.

\section{INTRODUCTION}

The genus Leishmania causes a variety of clinical syndromes ranging from self-healing cutaneous lesions through metastasing mucocutaneous forms to often lethal visceral manifestations. The severity of clinical manifestations in immunocompetent people depends, mainly, on the Leishmania species involved. Patients with leishmaniasis, associated with acquired immunodeficiency syndrome (AIDS), have revealed unusual immunopathological aspects. Most patients, suffering from LeishmaniaHIV co-infections, have shown atypical clinical profiles such as disseminated cutaneous leishmaniasis ${ }^{5,14}$, unusual cutaneous lesions s, $^{7,20}$, mucosal lesions containing abundant amastigote forms ${ }^{4,10,23}$, atypical mucocutaneous leishmaniasis caused by L. braziliensis ${ }^{6}$, cutaneous involvement due to viscerotropic parasites ${ }^{21}$ and visceral involvement due to dermotropic parasites ${ }^{12}$.

Leishmania has been reported to be an opportunistic parasite, in immunosuppressed patients ${ }^{2}$ and in immunocompromised individuals such as patients with HIV infection ${ }^{29}$, who live in endemic areas. The overlap between VL and AIDS has increased as a consequence of the spread of the pandemic AIDS in rural areas and that of VL to urban areas 9 . Consequently, cases of Leishmania/HIV co-infection are becoming more frequent with important clinical, diagnostic, chemotherapeutic, epidemiological and economic implications. The major features of VL clinical picture are: intermittent fever, spleen enlargement, pallor, fatigue, severe weight loss, loss of appetite and pancytopenia ${ }^{11}$. The disease is fatal if not treated. Although the incubation period of VL may vary from only 10 days to a year, the usual incubation period ranges from 2 to 4 months ${ }^{9,16}$.

Unfortunately, VL diagnosis is difficult in such patients, since serologic diagnosis is not sensitive enough and culture of Leishmania parasites is both time-consuming and not always positive. Molecular techniques for typing and diagnosing the etiological agent are very useful for specific therapy. PACHECO et al. ${ }^{17}$ described the isolation, genotypic and phenotypic characterization of a monoxenous trypanosomatid, found in the bone marrow of an HIV-positive patient, presenting a visceral leishmaniasis-like syndrome. Several authors have described PCR assays to be used as a diagnosis method ${ }^{8,19,20,25,26,27}$. The present article describes the case report of a VL patient, by L. braziliensis, and HIV co-infection.

\section{METHODS}

Indirect immunofluorescent assay (IFA): IFA, to detect antibodies in serum diluted from 1:40 to 1:640, was performed according to the manufacturer's instructions, using a commercial kit for the diagnosis of human leishmaniasis (FIOCRUZ/BIO-MANGUINHOS). The serological tests, on different Leishmania species, used weakly positive titers $\leq 1: 40$ and strongly positive titers $\geq 1: 80$ as IFA cutoff values.

Parasitological test: Cell culture from bone marrow aspirate material was performed in NNN/LIT medium, supplemented with $10 \%$ fetal calf serum and incubated at $24-25{ }^{\circ} \mathrm{C}$ for 30 days. For direct examination of bone marrow, the slides were stained with Giemsa and examined under light microscopy.

Research supported by the CNPq, PAPES/FIOCRUZ, CPqRR

(1) Laboratório de Leishmanioses, Centro de Pesquisas René Rachou, Belo Horizonte, MG, Brasil.

(2) Universidade do Estado de Minas Gerais, Centro de Pós-graduação e Pesquisa, Fundação Educacional de Divinópolis.

(3) Departamento de Bioquímica e Biologia Molecular, Fundação Oswaldo Cruz, IOC, Rio de Janeiro, RJ, Brasil.

(4) Centro Geral de Pediatria, FHEMIG, Belo Horizonte, MG, Brasil.

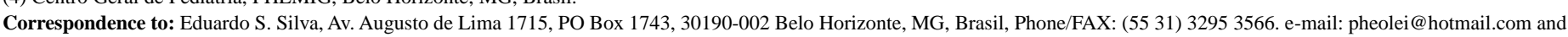
silvarii@cpqrr.fiocruz.br 


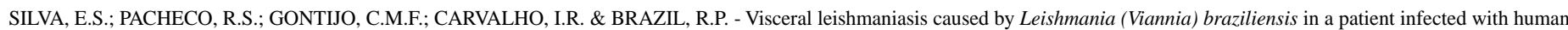
immunodeficiency virus. Rev. Inst. Med. trop. S. Paulo, 44(3):145-149, 2002.

DNA extraction : A volume of 20-30 $\mu \mathrm{l}$ of blood and bone marrow aspirates was transferred onto filter paper "FTA Cards" (Gibco BRL) and air-dried. A small portion of the sample, on FTA paper, was removed using a $2 \mathrm{~mm}$ punch and placed in a microcentrifuge tube with $200 \mu \mathrm{l}$ of lysis buffer (FTA processing reagent-Gibco BRL). The sample was washed for $5 \mathrm{~min}$ at room temperature and centrifuged three times at $13000 \mathrm{~g}$ for $5 \mathrm{~min}$, after which the supernatant was removed and discarded. A volume of $200 \mu \mathrm{TE}$ buffer (10 mM Tris-HCl, $1 \mathrm{mM}$ EDTA, [pH 7.5]) was added to, incubated for $5 \mathrm{~min}$ at room temperature and the supernatant was discarded after centrifugation, and the pellet ressuspended in $50 \mu \mathrm{l}$ TE. The paper-bound DNA was then ready for analysis; the paper punch containing purified DNA was directly used for PCR.

PCR 1: In order to amplify the conserved region of the minicircle molecule (Kinetoplastid mitochondrial DNA; kDNA), oligonucleotides (primer A: 5' - (G/C)(G/C)(C/G)CC(A/C)CTAT(A/T)TTACACCAACCCC; and primer B: 5' - GGGGAGGGGCGTTCTGCGAA) were used in a hotstart PCR procedure. Briefly, each reaction contained $100 \mathrm{ng}$ of the reverse and forward primers, $200 \mu \mathrm{M}$ of each deoxynucleoside triphosphate (Pharmacia, Uppsalla, Sweden), $2.5 \mathrm{U}$ of Taq polymerase (Perkin-Elmer, Norwalk, USA) in the buffer, as recommended by the manufacturer, and a small part of the DNA paper sample. PCR amplification was carried out in a DNA thermocycler (Perkin-Elmer) using 33 cycles at $94{ }^{\circ} \mathrm{C}$ for $30 \mathrm{~s}$; at $50{ }^{\circ} \mathrm{C}$ for $30 \mathrm{~s}$, and at $72{ }^{\circ} \mathrm{C}$ for $30 \mathrm{~s}$, with a extension cycle for $10 \mathrm{~min}$ at $72{ }^{\circ} \mathrm{C}$.

PCR 2: Specific PCR was carried out using the $B 1$ and $B 2$ primers (B1 - GGGGTTGGTGTAATATAGTGG and B2 CTAATTGTGCACGGGGAGG) specific for the L. braziliensis complex ${ }^{8}$. Cycles consisted of annealing at $63{ }^{\circ} \mathrm{C}$ for $1 \mathrm{~min}$, extension at $72{ }^{\circ} \mathrm{C}$ for $1 \mathrm{~min}$ and desnaturation at $93{ }^{\circ} \mathrm{C}$ for $30 \mathrm{~s}$. The programmes were run for 35 cycles on a Perkin Elmer thermocycler (Perkin-Elmer, USA), a final extension at $72{ }^{\circ} \mathrm{C}$ for $10 \mathrm{~min}$ was run.

Agarose gel electrophoresis: Each experiment included a positive control (reference strains of Leishmania) and a negative control (rabbit blood). Aliquots of $10 \mu \mathrm{l}$ of the PCR reaction were analyzed by agarose gel electrophoresis, at $100 \mathrm{~V}$, in the presence of ethidium bromide $(0.5 \mu \mathrm{g} / \mathrm{ml})$. The expected amplification products of $120 \mathrm{bp}$ (PCR 1$)$ and 750 bp (PCR 2) were visualized under UV light.

Positive and negative controls: The reference strains $L$. (L.) chagasi MHOM/BR/74/PP75 (code PP75); L. (V.) braziliensis MHOM/BR/75/ M2903 (code M2903) and L. (L.) amazonensis IFLA/BR/67/PH8 (code PH8) were used as positive controls. The promastigotes of such strains were transferred to the filter paper "FTA Cards" (Gibco BRL), to which rabbit blood was added after air dried. Rabbit blood, alone on filter paper, was used as a negative control. DNA from Leishmania reference strains and rabbit blood were prepared according to the protocols previously described.

Hybridization: PCR 1 products were transferred to nylon membranes with a dot-blot apparatus and hybridized with cloned $L$. braziliensis minicircles as molecular probe, radio-labeled with $\left[\alpha-{ }^{32} \mathrm{P}\right]$ dATP, by random hexamer priming. The transferred product was hybridized in Blotto at $65{ }^{\circ} \mathrm{C}$, washed in $0.1 \mathrm{X}$ sodium saline citrate at the same temperature, and exposed to X-ray films ${ }^{22}$.
Case report: In January 1998, a 19 month-old girl, from the small town of Martinho Campos, in the Brazilian state of Minas Gerais, was admitted to the General Pediatric Center, in Belo Horizonte with fever, pneumonia, lymphodenomegalia and hepatosplenomegalia. The girl's mother and father, aged 22 and 27 respectively, were both HIV-positive. The girl was delivered by caesarian section and weighed $3000 \mathrm{~g}$ at birth, with a body length of $50 \mathrm{~cm}$. The child was breast-fed by the mother until 3 months old. She suffered bouts of pneumonia at 3, 5, 6, 8, 9 and 13 months of age. At 8 months, she received two blood transfusions due to her recurrent medical profile of malnutrition, anemia, fever, pallor, hepatomegalia and splenomegalia. At 19 months, she was diagnosed as HIV-positive and received treatment with Zidovudine (AZT) $(120 \mathrm{mg} /$ $\mathrm{m}^{2}$ every $\left.8 \mathrm{~h}\right)$, Didadosine DDI $\left(100 \mathrm{mg} / \mathrm{m}^{2}\right.$ every $\left.12 \mathrm{~h}\right)$ and intravenous gammaglobulin. On physical examination, she was chronically ill appearing, febrile and pale. The spleen and liver were palpable, extending to 5 and $8 \mathrm{~cm}$ below the coastal margin. Laboratory data revealed platelets $(35,600 / \mu \mathrm{L})$, hemoglobin $(8.7 \mathrm{~g} / \mathrm{dL})$, normal erythrocyte, leukocytopenia. The patient subsequently experienced respiratory failure, due to AIDSrelated pneumocytosis, and died 8 weeks later.

\section{RESULTS}

Immunological test: A positive titer was observed for Leishmania antibodies (IFA 1:320). After 2 weeks of intermittent fever, another positive titer for Leishmania antibodies (IFA 1:160) was noted.

Parasitological studies: The results of Leishmania IFA were confirmed by visualization of amastigote forms, from bone marrow aspirate, after Giemsa staining (Fig. 1) and isolation of promastigote forms in culture. Specific therapy was initiated with intravenous administration of antimonial Glucantime ${ }^{\circledR}(20 \mathrm{mg} / \mathrm{Kg}$ body weight).

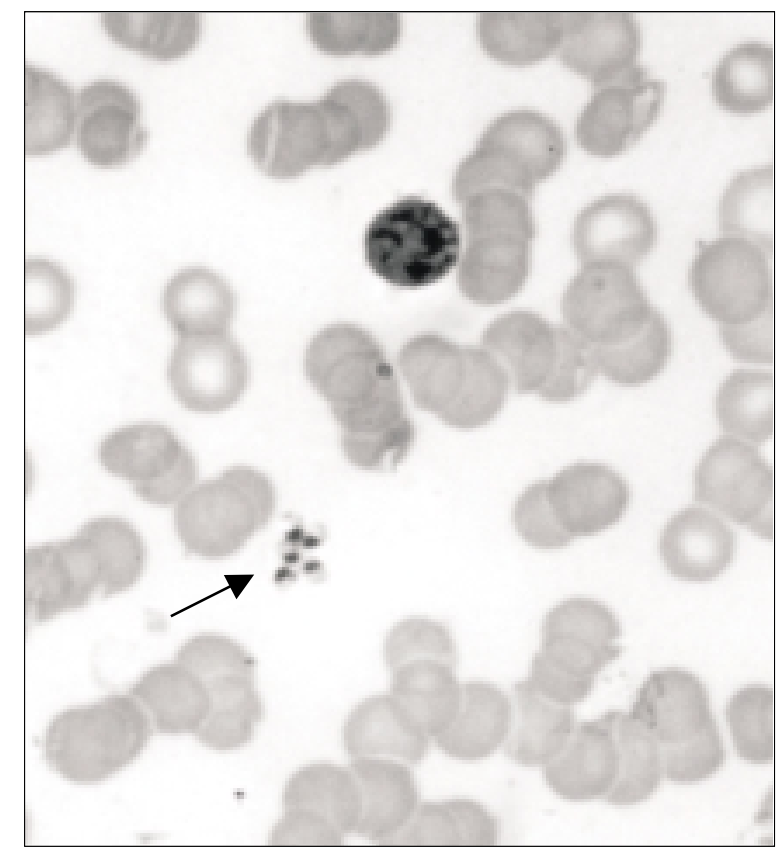

Fig. 1 - Smear of the bone marrow aspirate from a child with visceral leishmaniasis indicating presence of amastigotes (2-3 $\mu \mathrm{m}$ in diameter). 


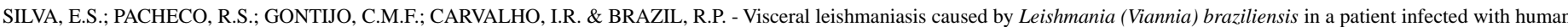
immunodeficiency virus. Rev. Inst. Med. trop. S. Paulo, 44(3):145-149, 2002.

PCR for the genus Leishmania: Purified DNA from the positive controls and the DNA, isolated from blood and bone marrow aspirate of the patient, also yielded an amplification product (Fig. 2a). The DNA purified from rabbit blood was negative for Leishmania, based on PCR analysis. No contamination or inhibition was detected.

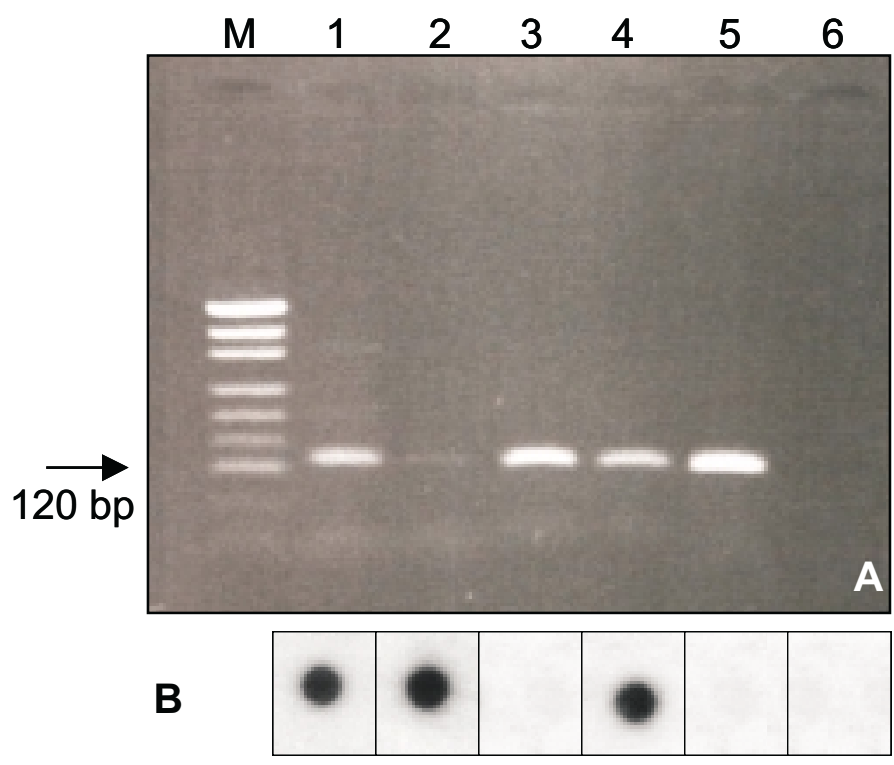

Fig. 2 - A. PCR products obtained with primers of the genus Leishmania visualized after $2 \%$ agarose gel electrophoresis stained with ethidium bromide. MW 50base-pair DNA ladder; lanes 1 and 2: bone marrow and blood from patient, lane 03: DNA of L. chagasi, lane 4: DNA of L. braziliensis, lane 5: DNA of L. amazonensis and lane 6: negative control. B. Hybridization with a cloned minicircle from L. braziliensis.

Specific PCR: The specific amplification of isolated DNA, from blood and bone marrow, provided an amplification band similar to the 750 bp kDNA amplification band of the L. (V.) braziliensis reference strain M2903. PCR did not amplify DNA of $L$. chagasi and $L$. amazonensis (Fig. 3).

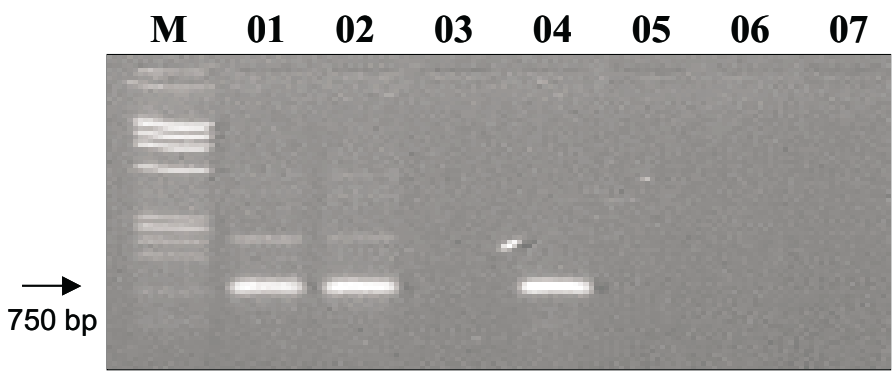

Fig. 3 - Specificity of PCR, with primers specific for L. braziliensis complex. Lane M: molecular weight marker (MWM) $\phi X 174$ Hae III, lanes 1 and 2: blood and bone marrow from patient, lane 3: L. (L.) chagasi, lane 4: $L$. (V.) braziliensis, lane 5: L. amazonensis, lane 6: negative control, lane 7: No DNA.

Hybridization: A hybridization signal was observed in the PCR product when hybridized against a cloned minicircle of Leishmania (Viannia) braziliensis used as probe (Fig. 2 b) thus, confirming the specificity of the primers B1/B2 for the L. braziliensis complex.
The parasite was identified as $L .(V$.) braziliensis using blood and bone marrow aspirate, the specific primer B1/B2 ${ }^{8}$ and PCR-hybridization analysis.

\section{DISCUSSION}

Leishmania/HIV co-infection is considered to be an emerging disease and a threat in several countries in accordance with WHO data. The global experience, mainly in European countries, is marked by an increasing number of co-infection cases in this decade, leading to modifications concerning the epidemiological profile, presentation and clinical outcome of visceral leishmaniasis in various countries.

Recent changes in the epidemiological profiles, identified by the AIDS and leishmaniasis control programs, in Brazil, such as the ruralization and pauperization of HIV infection and the simultaneous urbanization of leishmaniasis, point to a possible expansion of people at risk of acquiring both infections.

In Brazil, the number of cases of Leishmania/HIV co-infection is growing in several states, including both the cutaneous and visceral clinical presentation. However, the under-notification cases of coinfection remains a problem with important clinical and epidemiological implications ${ }^{29}$. DA-CRUZ et al. ${ }^{6}$ reported an atypical case of AIDSassociated mucocutaneous leishmaniasis, due to L. braziliensis. There are also a few reports of HIV-infected mucocutaneous leishmaniasis patients, associated or not with cutaneous lesions ${ }^{4,10,15,23}$. In a recent case report CHEHTER et al. ${ }^{3}$ described the involvement of the gastrointestinal tract and dissemination forms of Leishmania, in co-infection visceral leishmaniasis and HIV patient. In the present paper, atypical VL was caused by $L$. braziliensis and the patient did not show cutaneous or mucosal lesions. HERNANDEZ et al..$^{13}$ also demonstrated L. braziliensis as causing VL, in a patient with HIV infection. In our laboratory, we have isolated various parasite samples from inhabitants of Martinho Campos and characterized them as L. braziliensis; no other cases of VL have yet been reported from the region.

In the last few years, the number of human cases of visceral and cutaneous leishmaniasis, in the metropolitan region of Belo Horizonte $(\mathrm{MRBH})$, has increased, suggesting a rise in the transmission rates of Leishmania species $^{18,24}$. The clinical incubation period of VL typically ranges from 6 weeks to 6 months but may vary from 10 days to 10 years $^{1}$. The course of the disease is identical in children and adults. It may suddenly begin with high fever, vomiting, diarrhea, poor appetite, weight loss, lassitude and pallor and later produce splenomegaly, hepatomegaly, pancytopenia, lymphadenopathy and hyperglobulinemia. Untreated, the disease is fatal in $90 \%$ of cases within 1-3 years 9

HIV infection and Leishmania infection each induce important similar immunological changes, worsened when there is concomitant infection, such as a Th 1 to Th 2 response switch. However, the consequences of the viral infection predominate ${ }^{1}$. The inhibitory effect of HIV and Leishmania on cell proliferation and INF-gamma production is not due to IL-10 alone, but probably operates at the level of regulation of IFN-gamma-inducing factors, such as IL-12 and IL-18 ${ }^{28}$. Patients with HIV infection have depressed CD4+ cells, contributing to the visceralization of Leishmania infections ${ }^{6,28}$. In the present study, however, the patient had detectable anti-Leishmania antibodies (1:320), and parasitological tests showed to be positive for Leishmania in bone marrow samples. Positive PCR were obtained from the blood and bone marrow samples. The parasite was identified as Leishmania (V.) braziliensis using specific PCR and Southern blot analysis. The results reported here 


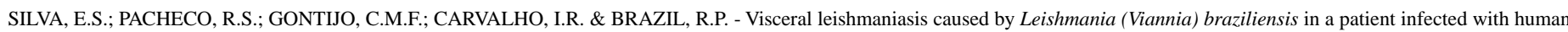
immunodeficiency virus. Rev. Inst. Med. trop. S. Paulo, 44(3):145-149, 2002.

reinforce the hypotesis that $L$. $(V$.) braziliensis is an opportunistic parasite producing severe manifestations that normally do not occur in immunocompetent individuals.

Specific diagnosis of leishmaniasis and characterization of parasites are, therefore, important prerequisites for treatment of immunocompromised patients in Leishmania-endemic areas, due to their increased risk of morbidity and mortality.

\section{RESUMO}

\section{Leishmaniose visceral causada por Leishmania (Viannia) braziliensis em paciente infectado com HIV}

No presente artigo os autores relatam caso de uma criança de 1 ano e 07 meses proveniente do estado de Minas Gerais com leishmaniose visceral causada por Leishmania (Viannia) braziliensis e co-infecção HIV. A mãe e o pai da criança de 22 e 27 anos de idade respectivamente também HIV positivo. A criança foi internada no Centro Geral de Pediatria em Belo Horizonte com febre alta, fadiga, perda de peso e aumento de fígado e baço. Foi realizado teste de imunofluorescência indireta para Leishmania e detectado título de 1:320. Este resultado foi confirmado com o encontro de amastigotas em aspirado de medula óssea e o crescimento de promastigotas em meios de cultura. Os parasitos foram identificados como Leishmania (Viannia) braziliensis utilizando PCR com primer específico para o complexo L. braziliensis, e primer genérico seguido de hibridização. Terapia específica para leishmaniose (antimonial de Glucantime) foi administrado por via intravenosa.

\section{ACKNOWLEDGMENTS}

We thank the General Pediatric Center, Belo Horizonte- FHEMIG/ Brazil for the clinical information of the patient.

\section{REFERENCES}

1. ALVAR, J.; CAÑAVATE, C.; GUTIÉRREZ-SOLAR, B. et al. - Leishmania and human immunodeficiency virus coinfection: the first 10 years. Clin. Microbiol. Rev., 10: 298-319,1997.

2. BADARO, R.; CARVALHO, E.M.; ROCHA, H. et al. - Leishmania donovani: an opportunistic microbe associated with progressive disease in three immunocompromised patients. Lancet, 1: 647-648, 1986.

3. CHEHTER, E.Z.; LONGO, M.A.; LAUDANNA, A.A. \& DUARTE, M.I.S. - Pancreatic involvement in co-infection visceral leishmaniasis and HIV: histological and ultrastructural aspects. Rev. Inst. Med. trop. S. Paulo, 43: 75-78, 2001.

4. CIMERMAN, S. \& GOMES, M.C.O. - AIDS associada a leishmaniose cutâneo mucosa. J. bras. Med., 65: 212-213, 1993.

5. COURA, J.R.; GALVÃO-CASTRO, B. \& GRIMALDI Jr., G. - Disseminated American cutaneous leishmaniasis in a patient with AIDS. Mem. Inst. Oswaldo Cruz, 82: 581-582, 1987.

6. DA CRUZ, A.M.; FILGUEIRAS, D.V.; COUTINHO, Z. et al. - Atypical mucocutaneous leishmaniasis caused by Leishmania braziliensis in a acquired immunodeficiency syndrome patient: T-cell responses and remission of lesions associated with antigen immunotherapy. Mem. Inst. Oswaldo Cruz, 94: 537-542, 1999.

7. DAUDÉN, E.; PEÑAS, P.F.; RIOS, L. et al. - Leishmaniasis presenting as a dermatomyositis-like eruption in AIDS. J. Amer. Acad. Derm., 35: 316-319, 1996.
8. DE BRUIJIN, M.H.L. \& BARKER, D.C. - Diagnosis of new world leishmaniasis: specific detection of species of the Leishmania braziliensis complex by amplification of kinetoplast DNA. Acta trop. (Basel), 52: 45-58, 1992.

9. DESJEUX, P.; PIOT, B.; O`NEILL, K. \& MEERT, J.P. - Co-infections a Leishmanial VIH dans le sud de l'Europe. Méd. trop., 61: 187-193, 2001.

10. ESCHEVARRÍA J.; CAMPOS, P.; CHANG, J. et al. - Mucocutaneous leishmaniasis and AIDS: case report. Trans. roy. Soc. trop. Med. Hyg., 87: 186, 1993.

11. GAGNAIRE, M.H.; GALAMBRUM, C. \& STÉPHAN, J.L. - Hemophagocytic syndrome: a misleading complication of visceral leishmaniasis in children. A series of 12 cases. Pediatrics, 106: E58, 2000

12. HERNANDEZ, D.; RODRIGUEZ, N.; MARTINEZ, C.; GARCIA, L. \& CONVIT, J. Leishmania braziliensis causing visceral leishmaniasis in a patient with human immunodeficiency virus infection, identified with the aid of the polymerase chain reaction. Trans. roy. Soc. trop. Med. Hyg., 87: 627-628, 1993.

13. HERNANDEZ, D.E.; RODRIGUEZ, N.; WESSOLOSSKY, M. \& CONVIT, J. -Visceral leishmaniasis due to a Leishmania variant that shares kinetoplast DNA sequences with Leishmania braziliensis and Leishmania mexicana in a patient infected with human immunodeficiency virus: identification of the Leishmania species with use of the polymerase chain reaction. Clin. infect. Dis., 21: 701-702, 1995.

14. MA, D.D.F.; CONCANNON, A.J. \& HAYES, J. - Fatal leishmaniasis in renal-tranport patient. Lancet, 2(8137): 311-312, 1979.

15. MACHADO, E.S.; BRAGA, M.P.; DA CRUZ, A.M. et al. - Disseminated American muco-cutaneous leishmaniasis caused by Leishmania braziliensis braziliensis in a patient with AIDS: a case report. Mem. Inst. Oswaldo Cruz, 87: 487-492, 1992.

16. MEINECKE, C.K.; SCHOTTELIUS, J.; OSKAM, L. \& FLEISCHER, B. - Congenital transmission of visceral leishmaniasis (Kala Azar) from an asymptomatic mother to her child. Pediatrics, 104: e65, 1999.

17. PACHECO, R.S.; MARZOCHI, M.C.A.; PIRES, M.Q. et al. - Parasite genotypically related to a monoxenous trypanosomatid of dog's flea causing opportunistic infection in an HIV-positive patient. Mem. Inst. Oswaldo Cruz, 93: 531-537, 1998.

18. PASSOS, V.M.A.; FALCÃO, A.L.; MARZOCHI, M.C.A. et al. - Epidemiological aspects of American cutaneous leishmaniasis in a periurban area of the metropolitan region of Belo Horizonte, MG, Brazil. Mem. Inst. Oswaldo Cruz, 88: 103-110, 1993.

19. PIARROUX, R.; GAMBARELLI, F.; DUMON, H. et al. - Comparison of PCR with direct examination of bone marrow aspiration, myeloculture, and serology for diagnosis of visceral leishmaniasis in immunocompromised patients. J. clin. Microbiol., 32: 746-749, 1994.

20. RODGERS, M.R.; POPPER, S.J. \& WIRTH, D.F. - Amplification of kinetoplast DNA as a tool in the detection and diagnosis of Leishmania. Exp. Parasit., 71: 267-275, 1990

21. RUBIO, F.A.; ROBAYNA, G.; HERRANZ, P. et al. - Leishmaniasis presenting as a psoriasiform eruption in AIDS. Brit. J. Derm., 136: 792-794, 1997.

22. SAMBROOK, J.; FRITCH, E.F. \& MANIATIS, T. - Molecular cloning. A laboratory manual. 2. ed. Cold Spring Harbor, Cold Spring Harbor Laboratory Press, 1989.

23. SASAKI, M.G.M.; CARVALHO, M.M.; FERREIRA, M.L.S. \& MACHADO, M.P. Cutaneous leishmaniasis coinfection in AIDS patients: case report and literature review. Braz. J. infect. Dis., 1: 142-144, 1997.

24. SILVA, E.S.; GONTIJO, C.M.F.; PACHECO, R.S.; FIUZA, V.O.P. \& BRAZIL, R.P. Visceral leishmaniasis in the metropolitan region of Belo Horizonte, state of Minas Gerais, Brazil. Mem. Inst. Oswaldo Cruz, 96: 285-291, 2001. 


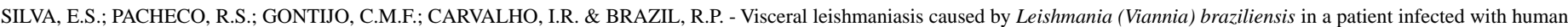
immunodeficiency virus. Rev. Inst. Med. trop. S. Paulo, 44(3):145-149, 2002.

25. SILVA, E.S.; PIRMEZ, C.; GONTIJO, C.M.F.; FERNANDES, O. \& BRAZIL, R.P. Visceral leishmaniasis in the crab-eating fox (Cerdocyon thous) in south-east Brazil. Vet. Rec., 147: 421-422, 2000.

26. SILVA, E.S.; GONTIJO, C.M.F.; PIRMEZ, C.; FERNANDES, O. \& BRAZIL, R.P. Detection of Leishmania DNA by Polymerase chain reaction on blood samples from dogs with visceral leishmaniasis. Amer. J. trop. Med. Hyg., 65: 896-898, 2001.

27. ULIANA, S.R.; AFFONSO, M.H.; CAMARGO, E.P. \& FLOETER WINTER, L.M. Leishmania: genus identification based on a specific sequence of the $18 \mathrm{~S}$ ribosomal RNA sequence. Exp. Parasit., 72: 157-163, 1991.
28. WOLDAY, D.; BERHE, N., BRITTON, S. \& AKUFFO, H. - HIV-1 alters T helper cytokines, interleukin-12 and interleukin-18 responses to the protozoan parasite Leishmania donovani. AIDS, 14: 921-929, 2000.

29. WORLD HEALTH ORGANIZATION - Report of the second WHO meeting on emerging infectious diseases. Geneva, World Health Organization, 1995. (WHO/CDS/BVI/ 95.2.)

Received: 17 August 2001

Accepted: 24 April 2002 